\title{
Stammerinema hyalinum n. comb. for Filaria hyalina von Linstow, 1890 and its recognition as a senior synonym of Stammerinema rhopalocephalum (Sołtys, 1952) (Spirurida: Acuariidae), a parasite of shrews
}

\author{
Yasen Mutafchiev $\cdot$ Jean Mariaux $•$ \\ Boyko B. Georgiev
}

Received: 24 October 2014/ Accepted: 1 December 2014

(C) Springer Science+Business Media Dordrecht 2014

\begin{abstract}
Based on a re-examination of type-specimens of Filaria hyalina von Linstow, 1890 from Sorex araneus L. (Mammalia: Soricidae) and morphological studies (light and scanning electron microscopy) of specimens collected from the same host species in Bulgaria and previously identified as Stammerinema rhopalocephalum (Sołtys, 1952), both these forms are considered to be conspecific. Accordingly, $F$. hyalina is transferred to the genus Stammerinema Osche, 1955 as Stammerinema hyalinum $\mathrm{n}$. comb. and the species originally described as Synhimantus rhopalocephalus Sołtys, 1952 is considered its junior synonym.
\end{abstract}

\section{Introduction}

The nematodes of the family Acuariidae Railliet, Henry \& Sisoff, 1912 form a diverse group

Y. Mutafchiev $(\bowtie) \cdot$ J. Mariaux

Natural History Museum of Geneva, 1 Route de

Malagnou, 1211 Geneva 6, Switzerland

e-mail: mutafchiev@gmail.com

Y. Mutafchiev $\cdot$ J. Mariaux

Department of Genetics and Evolution, University of Geneva, Boulevard d'Yvoy 4, 1205 Geneva, Switzerland

Y. Mutafchiev · B. B. Georgiev

Institute of Biodiversity and Ecosystem Research, Bulgarian Academy of Sciences, 2 Gagarin Street, 1113 Sofia, Bulgaria comprising mainly parasites of birds, rarely of mammals (Bain et al., 2014). The genus Stammerinema Osche, 1955 includes parasites of Soricidae (Mammalia) in the Holarctic Region. Quentin \& Wertheim (1986) considered three valid species within this genus: S. soricis (Tiner, 1951) Osche, 1955 (type-species), a parasite of Sorex monticolus Merriam (=Sorex obscurus alascensis Merriam) in Alaska, S. rhopalocephalum (Sołtys, 1952) Quentin \& Wertheim, 1986, a parasite of diverse European shrews, and S. globocephalum Quentin \& Wertheim, 1986, a parasite of Crocidura suaveolens (Pallas) (=Crocidura russula monacha Thomas) in Israel. Another spirurid species, Filaria hyalina von Linstow, 1890, was described from Sorex araneus L. (=Sorex vulgaris Nilsson) (see von Linstow, 1890). It was suspected to be a member of Stammerinema by Guerrero \& Bain (2011); however, due to the limited morphological information obtained from the type-specimens (posterior fragments of two males), they considered this species as incertae sedis.

In this article, we discuss the generic allocation of Filaria hyalina and its synonymy in view of new information obtained after our re-examination of the type-specimens from the collection of the Museum für Naturkunde, Berlin (ZMB), and its comparison with specimens of acuariid nematodes from shrews from Bulgaria identified as Stammerinema rhopalocephalum and studied by means of light and scanning electron microscopy (SEM). 


\section{Materials and methods}

The type-material of Filaria hyalina von Linstow, 1890 (ZMB Q3905, syntypes, from "Sorex vulgaris", type-locality not mentioned, posterior fragments of two male specimens) from the Helminthological Collection of the ZMB, was redescribed. In addition, the following samples from the stomach of Sorex araneus from Bulgaria deposited in the Helminthological Collection of the Institute of Biodiversity and Ecosystem Research, Bulgarian Academy of Sciences (IBER-BAS), Sofia, were studied:

- 1 entire male and posterior fragment of another male collected at Borovets (Rila Mountains) on 15.iv.1968, reported by Jančev (1974) as Skrjabinoclava soricis (Tiner, 1951) (IBER-BAS N001. 119);

- 2 entire females, two posterior fragments of females and 8 posterior fragments of males collected at Borovets (Rila Mountains) on 28.viii.1968, reported by Jančev (1974) as Skrjabinoclava soricis (Tiner, 1951) (IBER-BAS N001.120);

- posterior fragments of 4 males collected at Borovets (Rila Mountains) and reported by Jančev (1974), mounted on a SEM stub (IBER-BAS N001.121);

- 3 males collected at Krastatitsa Village (Rhodope Mountains) $\left(41^{\circ} 38^{\prime} 9^{\prime \prime} \mathrm{N}, 24^{\circ} 57^{\prime} 19^{\prime \prime} \mathrm{E}\right)$ on 5.xi.2007 by YM and BBG, IBER-BAS N001.123 (2 males, preserved in 70\% ethanol), IBER-BAS N001.121 (1 male mounted on a SEM stub);

- 1 male collected at Krastatitsa Village (Rhodope Mountains) $\left(41^{\circ} 38^{\prime} 9^{\prime \prime} \mathrm{N}, 24^{\circ} 57^{\prime} 19^{\prime \prime} \mathrm{E}\right)$ on 2.xi.2007 by $\mathrm{YM}$ and $\mathrm{BBG}$, used for molecular studies.

For light-microscopy, specimens were cleared and examined as temporary mounts in glycerol. Specimens used for SEM observations were transferred from $70 \%$ ethanol to $40 \%$ ethanol (10 min), rinsed in $0.1 \mathrm{M}$ cacodylate buffer, post-fixed in $1 \% \mathrm{OsO}_{4}$ for $2 \mathrm{~h}$ and dehydrated in an ethanol series. They were coated with gold in fine coater JEOL JFS 1200 and examined using a JEOL JSM 5510 microscope at $10 \mathrm{kV}$. Metrical data are given as the range, with the mean and the number of measurements taken (n) in parentheses. Measurements are in micrometres unless otherwise indicated.

DNA was extracted from a single male specimen and dissolved in $100 \mu \mathrm{TE}$ buffer. A fragment of the mitochondrial cytochrome oxidase $c$ subunit I (COI) gene was amplified using the newly-developed for the purposes of the present study on the basis of unpublished COI gene sequences of acuariid nematodes primers COI-F Acu2 (forward; 5'-TTT CCT CGT GTT AAT GCT TT-3') and COI-R Acu3 (reverse; 5'CAA ACA AAC GCT CCT TAT CAG A-3'). Polymerase chain reaction (PCR) amplifications were performed in a final volume of $50 \mu$ containing $1 \times$ CoralLoad PCR buffer (Qiagen), $0.2 \mathrm{mM}$ of each dNTP, 10 pmol of each primer, $1.5 \mathrm{U}$ Taq polymerase (Qiagen) and $1 \mu \mathrm{l}$ of DNA extract. The PCR cycling conditions were: $94^{\circ} \mathrm{C}$ for $1 \mathrm{~min}$ followed by 5 cycles of $94^{\circ} \mathrm{C}$ for $50 \mathrm{~s}, 47^{\circ} \mathrm{C}$ for $50 \mathrm{~s}$ and $72^{\circ}$ for $60 \mathrm{~s}$, followed by 30 cycles of $94^{\circ} \mathrm{C}$ for $50 \mathrm{~s}, 50^{\circ} \mathrm{C}$ for $50 \mathrm{~s}$, $72^{\circ} \mathrm{C}$ for $60 \mathrm{~s}$, and a final extension step of $72^{\circ} \mathrm{C}$ for 5 min. Sequencing was performed by Macrogen Inc. using the amplification primers.

Mammalian nomenclature follows Wilson \& Reeder (2005).

\section{Stammerinema hyalinum (von Linstow, 1890) n. comb.}

Syns Filaria hyalina von Linstow, 1890; Synhimantus rhopalocephalus Sołtys, 1952 (new synonymy); Stammerinema rhopalocephalum (Sołtys, 1952) Quentin \& Wertheim, 1986

\section{Redescription of the type-specimens (Fig. 1)}

[Based on posterior fragments of two male syntype specimens of Filaria hyalina (ZMB Q3905); measurements of the first specimen are followed by those of the second one given in parentheses.] Posterior body fragments 3.25 (5.99) $\mathrm{mm}$ long, with maximum width 274 (248). Cuticle 8-10 thick, with transverse striations 4-6 apart. Tail 207 (256) long; body width at cloaca 114 (137). Left spicule thin, 530 (519) long, with pointed distal end and composed of equal in length lamina and handle. Right spicule short and robust, 166 (174) long. Caudal alae 347 (416) long. Precloacal papillae represented by single ventral precloacal papilla and 4 pairs of subventral pedunculate papillae arranged in 2 groups each containing 2 pairs (Fig. 1A, B). Postcloacal papillae 6 pairs: 5 pairs of subventral pedunculate papillae and 1 pair of sessile papillae, situated between bases of last pedunculate papillae. Phasmids subterminal. 


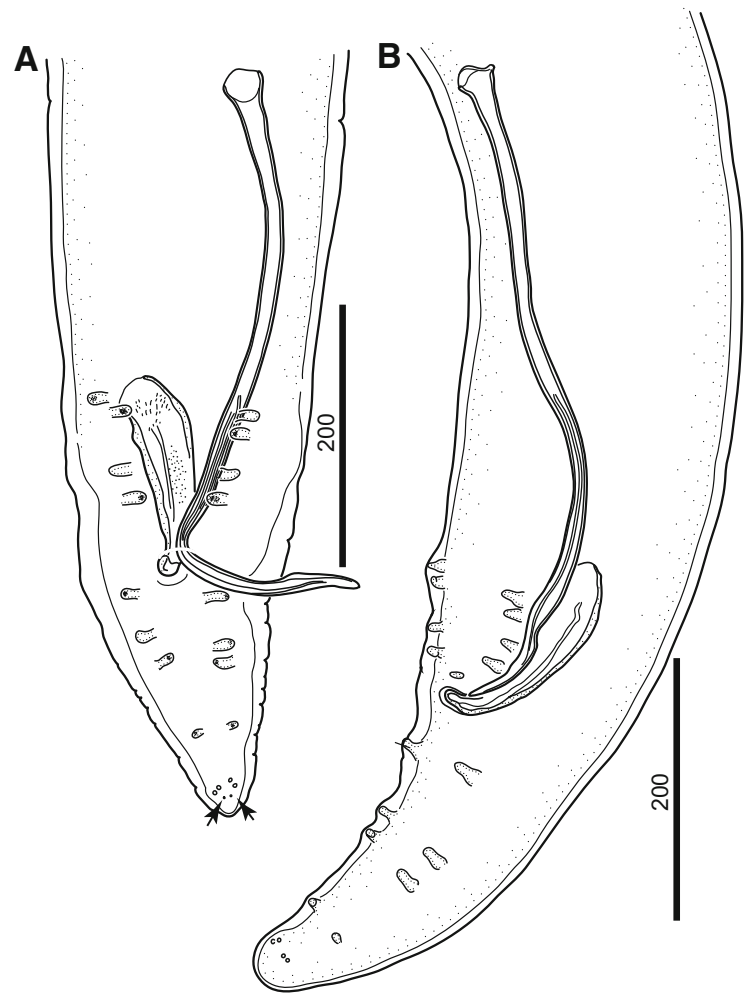

Fig. 1 Stammerinema hyalinum, syntypes (ZMB Q3905). A, Posterior end, ventral view, note phasmids (arrows); B, Posterior end, lateral view. All scale-bars are in micrometres

\section{Description of comparative materials (Figs. 2-3)}

General. [Based on specimens ex Sorex araneus from Bulgaria.] Anterior end with two small triangular pseudolabia, each bearing single amphid and pair of cephalic papillae (Fig. 3B). Body posterior to pseudolabia markedly swollen (Figs. 2A, B, 3A). Cordons arise dorsally and ventrally between pseudolabia, extending posteriorly beyond nerve-ring, recurrent in anterior direction and anastomosing (or may not anastomose) at level of mid-length of buccal cavity. Each cordon consists of 2 rows of cuticular plates with slightly serrate posterior rim, delimiting deep longitudinal gutter (Fig. 3B). Deirids small, spine-like, at level of posterior loop of cordons (Fig. 3C). Two lateral rows of small cuticular spines extend posterior to cordons and fade before mid-level of glandular oesophagus (Figs. 2A, 3C, D).

Male [Based on materials from Krastatitsa; $\mathrm{n}=3$, unless otherwise indicated.] Body 6.5-7.8 (7.3) mm long. Anterior end swollen, 385-424 (405) long, 312-393 (351) wide. Maximum body width 197-210 (204), measured at level of middle and posterior third of body length. Body width at level of cloaca 82-104 (92). Tail 195-225 (207) long. Cordons extended to 313-358 (338) from anterior body end, recurrent in anterior direction to 89-134 from anterior extremity, with maximum width 34-39 (36). Excretory pore at $376-425(401, \mathrm{n}=2)$ from anterior end. Buccal cavity 184-206 (196) long, 11-13 wide. Muscular oesophagus 633-654 (644, $\mathrm{n}=2)$ long, 54-57 (56) wide. Glandular oesophagus 2,910-3,011 $(2,961, \mathrm{n}=2)$ long, 79-100 (91) wide. Nerve-ring at $250(n=1)$ from anterior body end. Cuticle 7-9 thick, with transverse striations 5-6 apart. Caudal alae 335-375 (351) long. Precloacal papillae represented by single ventral precloacal papilla and 4 pairs of subventral pedunculate papillae arranged in 2 groups, each group consisting of 2 pairs (Figs. 2C, 3E). Postcloacal papillae 6 pairs: 5 pairs of subventral papillae and 1 pair of small papillae situated between bases of last pair of subventral papillae (Fig. 3F). Left spicule 479-523 (499) long, with pointed distal end; lamina and handle of equal length. Right spicule short, robust, 156-169 (161) long (Fig. 2D). Ratios: length of muscular oesophagus/length of glandular oesophagus $0.210-0.225$; length of oesophagus/body length $0.456-0.540$; length of caudal alae/body length $0.045-$ 0.053 ; length of left spicule/length of right spicule 2.935-3.353.

Female [Based on materials from Borovets; $\mathrm{n}=2$, unless otherwise indicated.] Body length 11.7-13.1 $\mathrm{mm}$. Anterior body end markedly swollen, 1,0321,089 long, 688-722 wide. Maximum body width measured posteriorly to swollen anterior end, 459-516, posterior to vulva. Body width 459-482 at level of vulva, 197-210 at level of anus. Cordons 516-528 long, 45-54 wide. Deirids and excretory pore not observed. Buccal cavity $258(\mathrm{n}=1)$ long. Muscular oesophagus $81(\mathrm{n}=1)$ wide. Glandular oesophagus 3,300 ( $\mathrm{n}=1)$ long, $121(\mathrm{n}=1)$ wide. Cuticle 5-6 thick, with transverse striations 8-9 apart. Vulva at 6.6-7.0 $\mathrm{mm}$ from anterior body end. Reproductive system didelphic-amphidelphic, extending in anterior direction to anterior swollen part of body. Vagina vera short, separated from short vagina uterina by welldeveloped sphincter (Fig. 2E). Tail 179-233 long (Fig. 2F). Eggs oval, with developed first-stage larva, 


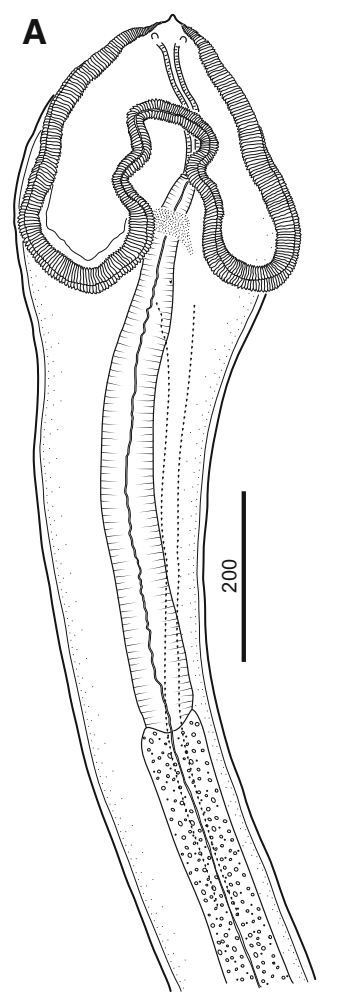

B
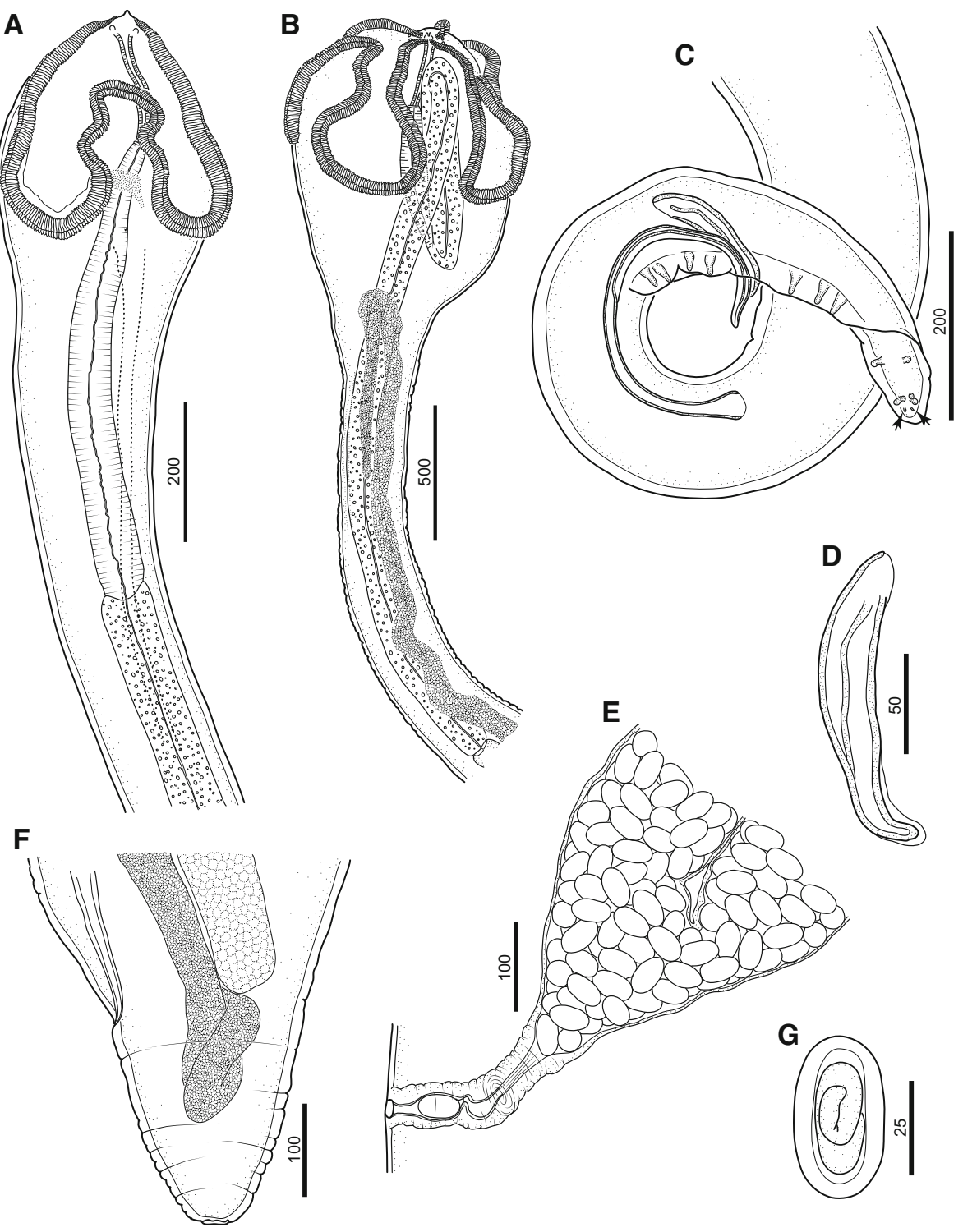

Fig. 2 Stammerinema hyalinum, comparative materials from Bulgaria. A, Anterior end, male, lateral view; B, Anterior end, female, lateral view; C, Posterior end, male, sinistral view, note phasmids (arrows); D, Right spicule, dextral view; E, Vagina, lateral view; F, Posterior end, female, lateral view; G, Egg. All scale-bars are in micrometres

43-44 × 22-24 ( $\mathrm{n}=10)$ (Fig. 2G). Ratio distance from vulva to posterior end/body length $0.537-0.563$.

Molecular identification

A fragment of $481 \mathrm{bp}$ of the COI gene was amplified. The nucleotide sequence is available in the GenBank database under accession no. KP059294. The closest available match after a query in the GenBank was a fragment of
COI gene of another acuariid species, Proyseria petterae Mutafchiev, Mariaux \& Georgiev, 2014, accession no. KJ995862, published by Mutafchiev et al. (2014).

\section{Discussion}

Osche (1955) synonymised Synhimantus rhopalocephalus Sołtys, 1952 with Dispharynx soricis Tiner, 

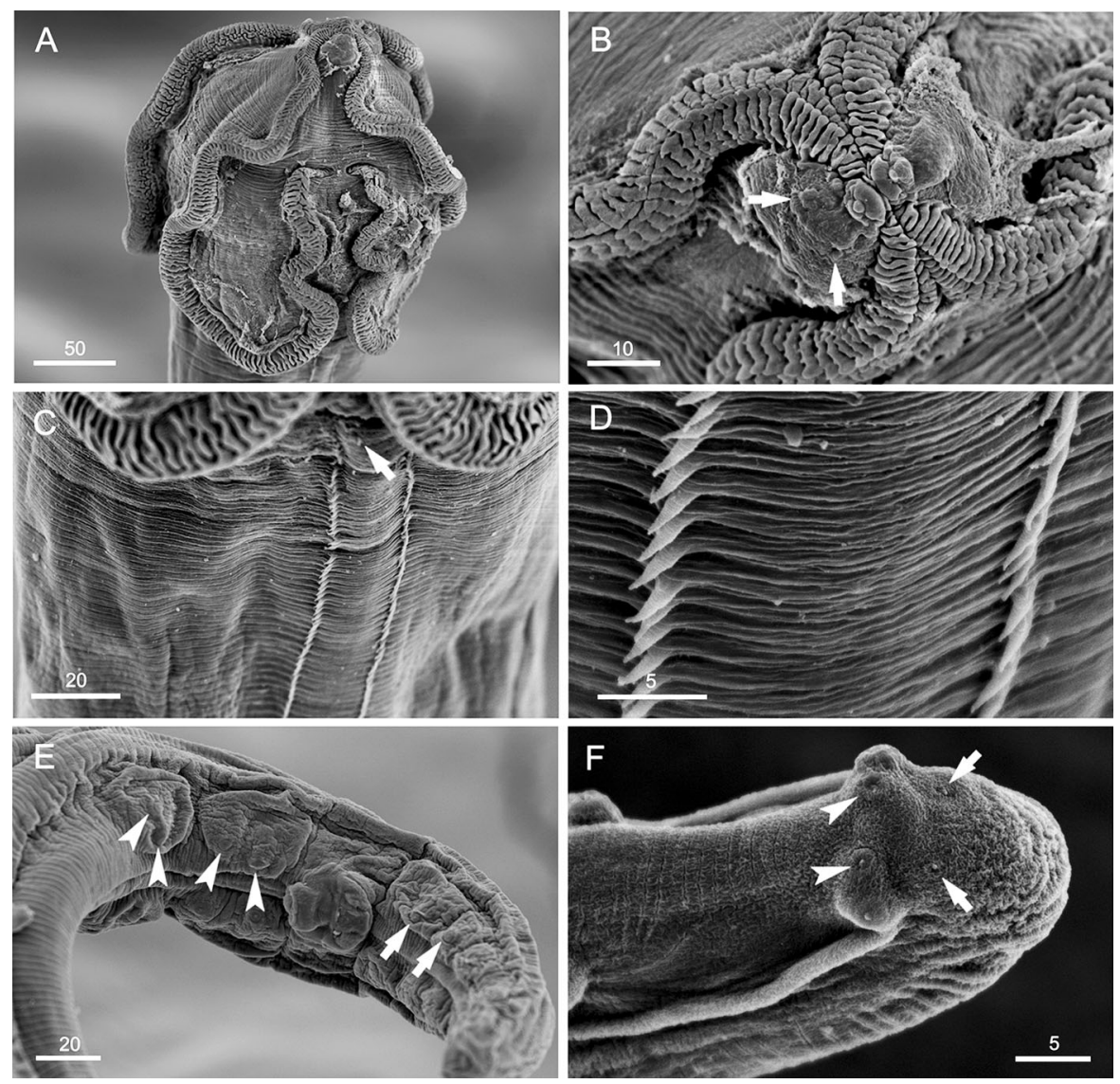

Fig. 3 Stammerinema hyalinum, comparative materials from Bulgaria, male, SEM. A, Anterior end, lateral view; B, Anterior end, apical view, note cephalic papillae (arrows); C, Detail from posterior end of cordons, lateral view, note two rows of cuticular spines and deirid (arrow); D, Lateral cuticular rows of spines; E, Posterior end, ventral view, note precloacal papillae (arrow heads) and postcloacal papillae (arrows); F, Tail extremity, ventral view, note a pair of small papillae (arrowheads) situated between bases of last pair of subventral papillae and phasmids (arrows). All scale-bars are in micrometres

1951 and erected the genus Stammerinema as monotypic. Skrjabin et al. (1965) did not accept Stammerinema as valid and considered it as a synonym of Skrjabinoclava Sobolev, 1943; they followed the synonymy of Dispharynx soricis and Synhimantus rhopalocephalus as proposed by Osche (1955). The subsequent records of nematodes belonging to this acuariid group and parasitising European shrews were referred as either Stammerinema soricis or Skrjabinoclava soricis (Tiner, 1951) Skrjabin, Sobolev \& Ivashkin, 1965 (see Merkusheva, 1966; Jančev, 1974; Jančev \& Stoykova-Hadjinikolova, 1980; Mészáros et al., 1982; Genov, 1984; Quentin \& Beveridge, 1986; Smogorzhevskaya, 1990; Matskási et al., 1996; Portolés et al., 2004). Quentin \& Wertheim (1986) recognised Synhimantus rhopalocephalus as valid and considered it as parasitic in European shrews only.
We agree with their decision for distinguishing $S$. soricis as described by Tiner (1951) and S. rhopalocephalum from European shrews as well grounded. Our observations based on Bulgarian material are in agreement with those by Quentin \& Wertheim (1986) that females of Stammerinema recorded in Europe differ from those of the other two congeneric species by the anterior swollen extremity, which takes smaller part of the body length and is not occupied by parts of the reproductive system.

The type-specimens of Filaria hyalina re-examined here correspond well to $S$. rhopalocephalum as described by Sołtys (1952) in the arrangement of the caudal papillae, the shape of the spicules as well as in the length of the right spicule. The left spicule of the specimens described by Sołtys (1952) is slightly shorter $(450-480$ vs 519-530 $\mu \mathrm{m})$, however this 
difference falls within the limits of intraspecific variation known for the acuariid nematodes (see Table 1). On this basis, we recognise $S$. rhopalocephalum as a junior synonym of Stammerinema hyalinum.

The specimens from $S$. araneus collected in Bulgaria and studied by us exhibit close morphology to $S$. hyalinum as well as to the previously described samples from Poland and the Ukraine (Table 1). Although they could be distinguished from those reported in France and Belgium by their smaller body dimension and shorter left spicule, they resemble them by the swollen anterior part, which is not occupied by the reproductive system.

The host range of S. hyalinum includes Sorex alpinus Schintz in Slovakia (Mészáros et al., 1982); Sorex araneus in Belgium (Bernard, 1961), France (Quentin \& Beveridge, 1986), Germany (Osche, 1955), Poland (Sołtys, 1952), Hungary (Matskási et al., 1996), Slovakia (Prokopič, 1956), Bulgaria (Jančev, 1974; Genov, 1984), Ukraine (Smogorzhevskaya, 1990), Belarus (Merkusheva, 1966); S. minutus L. in Germany (Osche, 1955), Poland (Sołtys, 1954), Hungary (Matskási et al., 1996), Bulgaria (Jančev, 1974; Genov, 1984); S. caecutiens Laxmann (=Sorex macropygmaeus karpinskii Dehnel) in Poland (Sołtys, 1954); Neomys fodiens (Pennant) in Germany (Osche, 1955), Poland (Sołtys, 1954); as larvae in the intestine and the abdominal cavity in Crocidura russula Hermann (see Portolés et al., 2004) and in the liver and the mesentery of one Crocidura suaveolens (Pallas) in Bulgaria (Jančev \& Stoykova-

Table 1 Metrical data of Stammerinema hyalinum ex Sorex araneus from various localities

\begin{tabular}{|c|c|c|c|c|c|c|c|}
\hline \multirow{3}{*}{$\begin{array}{l}\text { Source } \\
\text { Country }\end{array}$} & \multirow{3}{*}{$\begin{array}{l}\text { Sołtys } \\
(1952) \\
\text { Poland }\end{array}$} & \multirow{3}{*}{$\begin{array}{l}\text { Bernard } \\
\text { (1961) } \\
\text { Belgium }\end{array}$} & \multirow{3}{*}{$\begin{array}{l}\text { Quentin \& } \\
\text { Beveridge } \\
\text { (1986) } \\
\text { France }\end{array}$} & \multirow{3}{*}{$\begin{array}{l}\text { Smogorzhevskaya } \\
(1990) \\
\text { Ukraine }\end{array}$} & \multirow{3}{*}{$\begin{array}{l}\text { Genov } \\
(1984) \\
\text { Bulgaria }\end{array}$} & \multicolumn{2}{|l|}{ Present study } \\
\hline & & & & & & \multicolumn{2}{|l|}{ Bulgaria } \\
\hline & & & & & & Krastatitsa & Borovets \\
\hline Male & na & na & na & na & na & $(\mathrm{n}=3)$ & $(\mathrm{n}=1)$ \\
\hline Body length (mm) & $4.5-6.0$ & 8.6 & 9.5 & 6.5 & $5.9-7.4$ & $6.5-7.8$ & 6.4 \\
\hline Tail, length & - & 229 & $175-335$ & 250 & $226-241$ & $195-225$ & 159 \\
\hline Buccal cavity, length & - & 202 & 190 & & 189-194 & 184-206 & 161 \\
\hline $\begin{array}{l}\text { Muscular oesophagus, } \\
\text { length }\end{array}$ & - & 797 & 730 & 590 & $362-417$ & $633-654^{\mathrm{a}}$ & 465 \\
\hline $\begin{array}{l}\text { Glandular oesophagus, } \\
\text { length }\end{array}$ & - & 3,580 & 2,850 & 2,600 & $2,811-2,920$ & $2,910-3,011^{\mathrm{a}}$ & 2,149 \\
\hline Cordons, length & - & 476 & 430 & 410 & - & $313-358$ & 282 \\
\hline Left spicule, lenght & $450-480$ & 567 & 580 & 460 & $466-492$ & $479-523$ & 483 \\
\hline Right spicule, length & $160-170$ & 148 & $160-175$ & 150 & $154-172$ & $156-169$ & 152 \\
\hline Female & na & na & na & & na & & $(\mathrm{n}=2)$ \\
\hline Body length (mm) & $11.0-14.0$ & 16.6 & 15.8 & - & $9.5-15.7$ & - & $11.7-13.1$ \\
\hline Tail, length & - & 600 & 360 & - & - & - & $179-233$ \\
\hline Buccal cavity, length & - & 357 & 250 & - & $290-323$ & - & 258 \\
\hline $\begin{array}{l}\text { Muscular oesophagus, } \\
\text { length }\end{array}$ & - & 1,011 & 800 & - & 878-989 & - & - \\
\hline $\begin{array}{l}\text { Glandular oesophagus, } \\
\text { length }\end{array}$ & - & 4,339 & $4,600-4,900$ & - & $2,460-4,200$ & - & 3,300 \\
\hline Cordons, length & - & $833-960$ & 800 & - & - & - & $516-528$ \\
\hline $\begin{array}{l}\text { Vulva, distance from } \\
\text { anterior body end }\end{array}$ & $4.2-5.5$ & 7.8 & 6.5 & - & $5.7-6.9$ & - & $6.6-7.0$ \\
\hline Eggs & $\begin{array}{c}38-42 \times \\
25-29\end{array}$ & $\begin{array}{c}41-43 \times \\
22-24\end{array}$ & $43-26$ & - & $\begin{array}{c}42-46 \times \\
24-28\end{array}$ & - & $\begin{array}{r}43-44 \times \\
22-24^{\mathrm{b}}\end{array}$ \\
\hline
\end{tabular}

${ }^{\mathrm{a}} \mathrm{n}=2 ;{ }^{\mathrm{b}} \mathrm{n}=10 ;$ na data on the number of specimens examined not available 
Hadjinikolova, 1980). Based on these records, the predilection hosts of $S$. hyalinum seem to be insectivores of the genus Sorex L., whereas those from the genera Neomys Kaup and Crocidura Wagler are accidental.

The original spelling proposed by Quentin \& Wertheim (1986) for the Palaearctic species of the genus Stammerinema is "Stammerinema rhopalocephala" and "Stammerinema globocephala". According to Article 30 (30.1.2) of the International Code of Zoological Nomenclature (ICZN, 1999), the generic names ending in "-nema" are of neuter grammatical gender. Therefore, the proper spelling of the two species mentioned above is Stammerinema rhopalocephalum and Stammerinema globocephalum.

Acknowledgements This study was supported by Sciex$\mathrm{NMS}^{\mathrm{ch}}$ Program CRUS Switzerland. Authors are grateful to Dr B. Neuhaus (Museum für Naturkunde, Berlin) for lending specimens. We are grateful to an anonymous reviewer for the constructive criticism.

\section{References}

Bain, O., Mutafchiev, Y., \& Junker, K. (2014). Order Spirurida. In: Schmidt-Rhaesa, A. (Ed.) Handbook of Zoology: Gastrotricha, Cycloneuralia and Gnathifera. Volume 2. Nematoda. Berlin: De Gruyter, pp. 661-732.

Bernard, J. (1961). Quelques helminthes de micromammifères récoltés dans les Vosges. Vie et Milieu, 12, 357-373.

Genov, T. (1984). [Helminths of insectivores and rodents in Bulgaria.]. Sofia: Publishing House of the Bulgarian Academy of Sciences, 348 pp (In Bulgarian).

Guerrero, R., \& Bain, O. (2011). Study of types of some species of "Filaria" (Nematoda) parasites of small mammals described by von Linstow and Molin. Parasite, 18, 151-161.

ICZN International Commission on Zoological Nomenclature (1999). International Code of Zoological Nomenclature. Fourth Edition. London: International Trust for Zoological Nomenclature, $306 \mathrm{pp}$.

Jančev, J. (1974). Results of ecological and faunistical studies of helminth parasites in small mammals (Rodentia and Insectivora) at Borovets Resort, Samokov Region. Izvestiya na Zoologicheskiya Institut s Muzey, 49, 133-161 (In Bulgarian).

Jančev, J., \& Stoykova-Hadjinikolova, R. (1980). Helminthofauna of the small mammals (Rodentia and Insectivora) from the Parangalitsa and Ropotamo reservations in Bulgaria. Khelmintologiya, 9, 65-89 (In Bulgarian).

Matskási, I., Mészáros, F., Murai, É., \& Gubányi, A. (1996) Helminthological investigations of vertebrates in the Bükk National Park (Monogenea, Digenea, Cestoda, Acanthocephala, Nematoda) In: Mahunka, S. (Ed.) The Fauna of the Bükk National Park. Budapest: Hungarian Natural History Museum, pp. 11-32.

Merkusheva, I. V. (1966). [Helminth fauna in the common shrew (Sorex araneus L.) in Belarus]. Materialy $k$
Nauchnoy Konferentsii Vsesoyuznogo Obschestva Gel'mintologov, 3, 178-183 (In Russian).

Mészáros, F., Murai, E., \& Matskási, I. (1982). Helminths of Sorex alpinus Schinz, 1837 (Trematoda, Cestoda, Nematoda, Acanthocephala) in the West-Carpathian Mountains (Slovakia). Parasitologica Hungarica, 14, 83-86.

Mutafchiev, Y., Mariaux, J., \& Georgiev, B. B. (2014). Description of Proyseria petterae n. sp., with an amended generic diagnosis and a review of the species of Proyseria Petter, 1959 and Stegophorus Wehr, 1934 (Nematoda: Acuariidae). Systematic Parasitology, 89, 3-14.

Osche, G. (1955). Bau, Entwicklung und systematische Bedeutung der Cordons der Acuariidae (Nematoda) am Beispiel von Stammerinema soricis (Tiner 1951) gen. nov. Zeitschrift für Parasitenkunde, 17, 73-92.

Portolés, E., Granel, P., Esteban, J. G., \& Cabaret, J. (2004). Helminth associations in white-toothed shrews Crocidura russula (Insectivora: Soricidae) from the Albufera Natural Park, Spain. Journal of Parasitology, 90, 572-578.

Prokopič, J. (1956). Helmintofauna rejska obecneho (Sorex araneus L.) v ČSR. Československá Parasitologie, 3, 109-131.

Quentin, J.-C., \& Beveridge, I. (1986). Comparative morphogenesis of the cephalic structures of the acuariid nematodes Stammerinema soricis (Tiner, 1951), Antechiniella suffodiax (Beveridge \& Barker, 1975) n. g., n. comb. and Skrjabinoclava thapari (Teixeira de Freitas, 1953). Systematic Parasitology, 8, 163-171.

Quentin, J.-C., \& Wertheim, G. (1986). Description de Stammerinema globocephala n. sp. (Nematoda, Acuarioidea) parasite de Crocidura russula (Insectivora, Soricidae) d'Israël. Bulletin du Muséum National d'Histoire Naturelle, 8, 285-293.

Skrjabin, K. I., Sobolev, A. A., \& Ivashkin, V. M. (1965). [Spirurata of animals and man and the diseases caused by them. Part 3. Acuarioidea]. In: Skrjabin, K. I. (Ed.) Osnovy Nematodologii. Vol. 14. Moscow: Nauka, 572 pp (In Russian).

Smogorzhevskaya, L. A. (1990). [Nematodes. Part 3. Acuarioidea]. In: Sharpilo, V. P. (Ed.) Fauna Ukrainy. Vol. 32. Kiev: Naukova Dumka, 189 pp (In Russian).

Sołtys, A. (1952). Pasożyty wewnętrzne ryjówki aksamitnej (Sorex araneus L.) Białowieskiego Parku Narodowego. Annales Universitatis Mariae Curie Skłodowska, Sectio C, 5, 165-208.

Sołtys, A. (1954). Helmintofauna ryjówkowatych (Soricidae) Białowieskiego Parku Narodowego. Acta Parasitologica Polonica, 1, 353-402.

Tiner, J. D. (1951). Dispharynx soricis n. sp. (Nematoda: Acuariidae) from the shrew Sorex obscurus alascensis and associated host pathology. Proceeding of the Helminthological Society of Washington, 18, 64-70.

von Linstow, O. (1890). Beitrag zur Kenntniss der Vogeltänien nebst Bemerkungen über neue und bekannte Helminthen. Archiv für Naturgeschichte, 56, 171-188.

Wilson, D. E., \& Reeder, D. A. (Eds) (2005). Mammal Species of the World. A Taxonomic and Geographic Reference. Third Edition. Baltimore, Maryland: Johns Hopkins University Press, 2142 pp. 